\title{
U-Th-Pb Ages of Megacrystic Zircon from the Monastery Kimberlite, Free State, South Africa
}

\author{
Zartman, R.E. ${ }^{1}$, Richardson, S.H. ${ }^{1}$, Gurney, J.J. ${ }^{1}$, and Moore, R.O. ${ }^{2}$ \\ 1. Department of Geological Sciences, University of Cape Town, Rondebosch 7700, South Africa \\ 2. \#3-1419 Pendrewl Street, Vancouver V6G 1S3, Canada
}

Precise emplacement ages of individual diatremes are needed to unravel the extended geochemical and tectonic history of many kimberlite provinces. Two decades ago Davis et al. (1976) and Davis (1977) established the usefulness of zircon in defining the eruptive ages of Cretaceous and Early Tertiary kimberlites on and peripheral to the southern African Kaapvaal Craton. Their ability to date zircon of presumed mantle origin, which was significantly lower in $\mathrm{U}$ and radiogenic $\mathrm{Pb}$ content than the crustal zircon previously analyzed, was attributable to improvements in the purification of chemical reagents and to the development of a hydrothermal method of sample digestion (Krogh, 1973). Nevertheless, at that time when even the improved chemistry $\mathrm{Pb}$ blank was still of the order of $100 \mathrm{pg}$, only the ${ }^{206} \mathrm{~Pb} /{ }^{238} \mathrm{U}$ ages could be calculated with sufficient radiogenic $\mathrm{Pb}$ enrichment to be given a $\pm 1.5 \%$ uncertainty. More recently, both conventional (Schärer et al., 1997) and ion microprobe (Kinny et al., 1989) mass spectrometry have been employed to investigate in some detail the U-Pb isotopic systematics of kimberlite zircon from specific localities, but in both cases zircon with either older ages or higher $U$ contents than reported here were involved.

The present study evaluates the U-Th-Pb dating of zircon with especially low $\mathrm{U}$ content (3-14 ppm) and relatively young age ( $90 \mathrm{Ma})$ from the Monastery kimberlite, Free State, South Africa. Previously, Davis et al. (1976) had reported a ${ }^{206} \mathrm{~Pb} /{ }^{238} \mathrm{U}$ age of $90.4 \mathrm{Ma}$ and a $U$ content of 6.1 ppm--the lowest encountered from southern African localities--for a single Monastery zircon. Subsequently, several hundred rounded crystals of zircon were retrieved from this kimberlite in 1981-82 during a short period of renewed mining activity. The zircon, together with other large $(>1 \mathrm{~cm})$, single crystal minerals (olivine, orthopyroxene, clinopyroxene, garnet, ilmenite, and phlogopite), belongs to a distinctive suite of Cr-poor megacrysts, which has been interpreted by Moore (1986; see also Gurney et al., 1979; Moore et al., 1992) to have crystallized out of a highly evolved liquid that differentiated from the parental magma of the kimberlite.

Ten crystal fragments of several mm dimension and ranging in color from completely colorless to medium amber yellow were chosen to determine their U-Th- $\mathrm{Pb}$ ages and compositional variability within the suite. Each fragment was crushed in an alumina mortar and sieved to retain only the $-100+40 \mu \mathrm{m}$ fraction for analysis. In order to reduce surface contamination, the crushed samples were washed in warm $1 \mathrm{~N} \mathrm{HNO}_{3}$ and $1 \mathrm{~N} \mathrm{HCl}$, rinsed in distilled water, and dried before 1-2 mg splits were weighed into $1 \mathrm{~mL}$ teflon digestion vessels. Analytical procedure closely followed the hydrothermal bomb and anion resin exchange column method of Krogh (1973) for milligram size samples except as noted below. A mixed ${ }^{205} \mathrm{~Pb}-{ }^{235} \mathrm{U}-$ ${ }^{230} \mathrm{Th}$ spike was employed--making it possible to determine $\mathrm{Th}-\mathrm{Pb}$ as well as $\mathrm{U}-\mathrm{Pb}$ ages and to directly measure $\mathrm{Th} / \mathrm{U}$ ratios.

The results of twelve analyses performed in the Radiogenic Isotope Laboratory of the University of Cape Town on the zircon megacrysts are presented in Table 1. At the time these data were obtained the laboratory $\mathrm{Pb}$ blank, which accounted for half or more of the common $\mathrm{Pb}$ in the analysis, fluctuated between 25 and $15 \mathrm{pg}$. Consequently, for many of the analyses the measured ${ }^{206} \mathrm{~Pb} /{ }^{204} \mathrm{~Pb}$ of $187-845$ translates into rather large common $\mathrm{Pb}$ corrections and significant ${ }^{207} \mathrm{~Pb} /{ }^{206} \mathrm{~Pb}$ age uncertainties. For consistency the $\mathrm{Pb}$ isotopic composition of all 
samples has been corrected for $20 \mathrm{pg}$ of laboratory blank, and the remaining common $\mathrm{Pb}$ is assumed to have a Stacey and Kramers (1975) 90 Ma model isotopic composition. As with prior efforts to date such young and unradiogenic zircon, the U-Pb (and Th- $\mathrm{Pb}$ ) ages are analytically most precise, and, assuming no postcrystallization loss of radiogenic $\mathrm{Pb}$, provide the best constraint on the time of kimberlite emplacement. An independent measurement of initial $\mathrm{Pb}$ isotopic composition has not yet been made, but only the three samples with ${ }^{206} \mathrm{~Pb} /{ }^{204} \mathrm{~Pb}<300$ would have their ${ }^{206} \mathrm{~Pb} /{ }^{238} \mathrm{U}$ ages changed by more than $0.2 \mathrm{Ma}$ if any reasonable isotopic composition for the mantle were substituted for the Stacey and Kramers model ratios.

Isotopic equilibration between sample and spike is essential to parent-daughter ages, and it is important to demonstrate the reproducibility of the analytical technique, especially in terms of complete sample digestion and sample/spike homogenization. Two approaches have been taken in this regard, (1) consistency of ages among a presumed cogenetic zircon population, and (2) replicate analyses of a 'standard' sample. All of the results reported in Table 1 were determined in three chemistry sessions (A, B, and C, sequentially), which, although using the same basic Krogh technique, differed from each other in several aspects. Sessions A and B involved a second HF digestion to insure complete dissolution of the sample, but after no evidence of an undissolved residue was found, a single digestion was used in session C. Also, total digestion time was progressively reduced from six weeks to four weeks to two weeks for sessions $\mathrm{A}, \mathrm{B}$, and $\mathrm{C}$, respectively, with presumably no deleterious effects. The anion resin exchange columns were operated in the bromide rather than chloride mode in session $\mathrm{B}$, but were returned to the chloride mode when poor Th recovery was experienced when the columns were used in the bromide mode.

The close grouping of ${ }^{206} \mathrm{~Pb} /{ }^{238} \mathrm{U}$ ages between $89.2 \pm 0.4$ and $92.8 \pm 0.5 \mathrm{Ma}$, although extending beyond the quoted uncertainties, suggests that no major difficulties were encountered with the chemical procedure. Interestingly, the 'standard' grain (grain 10), which was analyzed twice in session $B$ and once in session $C$, gives ages spanning the entire range of the grouping. One discredited analysis in session $\mathrm{B}$ did yield an anomalous ${ }^{206} \mathrm{~Pb} /{ }^{238} \mathrm{U}$ age of $105 \mathrm{Ma}$, but a repeat analysis of the same sample in session $C$ failed to reproduce the discrepant result. Even so, this probable extreme case of incomplete mixing between sample and spike does raise the possibility that minor sample-spike disequilibrium might be the cause of some spread within the grouping itself. Without a priori criteria for excluding any of the analyses, however, a weighted average ${ }^{206} \mathrm{~Pb} /{ }^{238} \mathrm{U}$ age of $90.1 \pm 0.5 \mathrm{Ma}[\mathrm{MSWD}=3.9$, sample 10-2 rejected; Ludwig, 1996] is currently considered the best value for the time of zircon passage below its blocking temperature for diffusive $\mathrm{Pb}$ loss, presumably in response to diatreme emplacement. This result is indistinguishable from the weighted average ${ }^{207} \mathrm{~Pb} /{ }^{235} \mathrm{U}$ and ${ }^{208} \mathrm{~Pb} /{ }^{232} \mathrm{Th}$ ages of $90.0 \pm 0.5$ [MSWD $=1.7$, sample 10-2 rejected] and 89.5 $\pm 1.0 \mathrm{Ma}[\mathrm{MSWD}=2.1]$, respectively. Although the ${ }^{207} \mathrm{~Pb} /{ }^{206} \mathrm{~Pb}$ ages have significantly greater uncertainties, they do scatter around the U-Pb and $\mathrm{Th}-\mathrm{Pb}$ ages, and, thus, show no evidence of older radiogenic $\mathrm{Pb}$ inheritance, such as found by Schärer et al. (1997) for the Zairian Mbuji-Mayi kimberlite. Moreover, if any of the spread observed in the parent-daughter ages is to be attributed to pre-eruption mantle residence, that earlier 'memory' is restricted to only 2-3 Ma.

A positive correlation seems to exist between the measured $\mathrm{Th} / \mathrm{U}$ ratios and increasing Th and $U$ contents of the zircon. The geochemical significance of this relationship, or its correlation with any other trace elements, however, is not known but deserves further investigation. Except to set a general upper limit of $\sim 10 \mathrm{ppb}$ on the common $\mathrm{Pb}$ content of the zircon, this study can provide little insight into its distribution among samples until there is additional reduction in the laboratory $\mathrm{Pb}$ blank. 


\section{References}

Davis, G.L., Krogh, T.E., and Erlank, A.J., 1976, The age of zircons from kimberlites from South Africa: Carnegie Inst. Yr. Bk. 75, 821-824.

Davis, G.L., 1977, The age and uranium contents of zircons from kimberlites and associated rocks: Ext. Abstr. 2nd int. Kimberlite Conf. (Santa Fe, 1977).

Gurney, J.J., Jakob, W.R.O., and Dawson, J.B., 1979, Megacrysts from the Monastery kimberlite pipe, South Africa. In: Boyd, F. R., and Meyer, H.O.A. (eds.) The Mantle Sample: Inclusions in Kimberlites and Other Volcanics. AGU; Washington, 227-243.

Kinny, P.D., Compston, W., Bristow, J.W., and Williams, I.S., 1989, Archaean mantle xenocrysts in a Permian kimberlite: two generations of kimberlitic zircon in Jwaneng DK2, southern Botswana. In: Ross, J. (ed.) Kimberlites and Related Rocks. Geol. Soc. Aust. Spec. Publ. 14, 833-842.

Krogh, T.E., 1973, A low-contamination method for hydrothermal decomposition of zircon and extraction of $\mathrm{U}$ and $\mathrm{Pb}$ for isotopic age determination: Geochim. Cosmochim. Acta 37, 485-494.

Ludwig, K.R., 1996, Isoplot, a plotting and regression program for radiogenic-isotope data: U.S. Geol. Survey Open-File Rept. 91-445, version 2.90, 47 p.

Moore, R.O., 1986, A study of the kimberlites, diamonds and associated rocks and minerals from the Monastery Mine, South Africa: Ph.D. thesis, University of Cape Town.

Moore, R.O., Griffin, W.L., Gurney, J.J., Ryan, C.G., Cousens, D.R., Sie, S.H., and Suter, G.F., 1992, Trace element geochemistry of ilmenite megacrysts from the Monastery kimberlite, South Africa: Lithos 29, 1-18.

Schärer, U., Corfu, F., and Demaiffe, D., 1997, U-Pb and Lu-Hf isotopes in baddeleyite and zircon megacrysts from the Mbuji-Mayi kimberlite: constraints on the subcontinental mantle: Chem. Geol. 143, 1-16.

Table 1. U-Th-Pb zircon ages for the Monastery kimberlite.

\begin{tabular}{|lcccccccccc|}
\hline \multicolumn{1}{|c}{$\begin{array}{c}\text { Grain } \\
\text { Description }\end{array}$} & $\begin{array}{c}\text { Weight } \\
(\mathrm{mg})\end{array}$ & $\begin{array}{c}\text { Measured } \\
{ }^{206} \mathrm{~Pb} /{ }^{204} \mathrm{~Pb}\end{array}$ & $\mathrm{U}$ & $\mathrm{Th}$ & $\mathrm{Pb}_{\mathrm{rad}}{ }^{2}$ & $\mathrm{Th} / \mathrm{U}$ & ${ }^{206} \mathrm{~Pb} /{ }^{238} \mathrm{U}$ & ${ }^{207} \mathrm{~Pb} /{ }^{235} \mathrm{U}$ & ${ }^{207} \mathrm{~Pb} /{ }^{206} \mathrm{~Pb}$ & ${ }^{208} \mathrm{~Pb} /{ }^{232} \mathrm{Th}$ \\
\hline 1B, colorless & 2.08 & 203 & 3.06 & .72 & .0417 & .235 & $90.1 \pm 1.1$ & $90.2 \pm 2.6$ & $109 \pm 29$ & $92.5 \pm 2.9$ \\
2A, colorless & 1.96 & 235 & 3.63 & .76 & .0486 & .208 & $89.3 \pm 1.0$ & $89.4 \pm 2.3$ & $77 \pm 27$ & $88.1 \pm 3.5$ \\
3C, colorless & 1.24 & 187 & 4.27 & .86 & .0569 & .202 & $89.2 \pm 1.4$ & $88.8 \pm 3.2$ & $79 \pm 32$ & $88.3 \pm 3.8$ \\
4A, lt. yellow & 2.55 & 345 & 6.53 & 1.49 & .0880 & .229 & $89.7 \pm 0.9$ & $89.2 \pm 1.8$ & $75 \pm 20$ & $85.3 \pm 4.0$ \\
5C, lt. yellow & 1.21 & 424 & 6.97 & 2.00 & .0978 & .287 & $91.7 \pm 0.8$ & $91.6 \pm 1.5$ & $89 \pm 15$ & $90.1 \pm 2.1$ \\
6A, med. yellow & 2.05 & 536 & 9.77 & 2.36 & .1337 & .242 & $90.6 \pm 0.7$ & $90.0 \pm 1.0$ & $76 \pm 12$ & $88.2 \pm 1.6$ \\
7B, med. yellow & 2.28 & 450 & 9.87 & 2.59 & .1360 & .262 & $90.7 \pm 0.8$ & $90.2 \pm 1.3$ & $78 \pm 14$ & $88.0 \pm 2.5$ \\
8C, med. yellow & .98 & 324 & 10.55 & 2.67 & .1445 & .253 & $90.2 \pm 0.9$ & $90.5 \pm 1.9$ & $97 \pm 21$ & $89.6 \pm 2.8$ \\
9A, med. yellow & 2.43 & 628 & 11.35 & 3.69 & .1590 & .326 & $90.3 \pm 0.6$ & $90.9 \pm 0.9$ & $107 \pm 10$ & $90.9 \pm 1.3$ \\
10-1B, med. yellow & 1.10 & 513 & 14.69 & 4.97 & .2056 & .339 & $89.8 \pm 0.7$ & $89.4 \pm 1.1$ & $77 \pm 13$ & $90.7 \pm 1.8$ \\
10-2B, med. yellow & 1.67 & 693 & 14.76 & 5.06 & .2124 & .343 & $92.8 \pm 0.6$ & $93.0 \pm 0.7$ & $100 \pm 8$ & $88.5 \pm 1.5$ \\
10-3C, med. yellow & 2.11 & 845 & 14.86 & 5.14 & .2069 & .346 & $89.2 \pm 0.5$ & $89.3 \pm 0.6$ & $94 \pm 5$ & $90.1 \pm 1.2$ \\
\hline
\end{tabular}

Decay constants: ${ }^{238} \mathrm{U}=1.55125 \times 10^{-10} \mathrm{yr}^{-1} ;{ }^{235} \mathrm{U}=9.8485 \times 10^{-10} \mathrm{yr}^{-1} ;{ }^{232} \mathrm{Th}=4.9475 \times 10^{-11} \mathrm{yr}^{-1}$; ${ }^{238} \mathrm{U} /{ }^{2354} \mathrm{U}=137.88$. Letter following grain number (e.g., 4A) indicates chemistry session. 1 Corrected for fractionation and spike only. $2 \mathrm{~Pb}_{\mathrm{rad}}$, radiogenic $\mathrm{Pb}$, corrected for $20 \mathrm{pg}$ of laboratory blank and a Stacey and Kramers (1975) $90 \mathrm{Ma}$ model isotopic composition. 